\title{
COMMENTARY
}

\section{New sources of $\beta$-cells for treating diabetes}

\author{
Subhshri Sahu, David Tosh ${ }^{\mathbf{1}}$ and Anandwardhan A Hardikar \\ Stem Cells and Diabetes Section, National Center for Cell Science, Ganeshkhind Road, Pune 411007, India \\ ${ }^{1}$ Center for Regenerative Medicine, University of Bath, Bath BA2 7AY, UK \\ (Correspondence should be addressed to A A Hardikar; Email: anand@isletbiology.com)
}

\begin{abstract}
The treatment of diabetes by islet transplantation is presently hampered by the shortage of organ donors. The generation of insulin-producing cells is therefore a major objective in the long-term goal of curing diabetes. Alternative sources of pancreatic $\beta$-cells include existing pancreatic cells, embryonic stem cells, and cells from other tissues such as liver. This

commentary considers evidence for two new sources of $\beta$-cells: intrahepatic biliary epithelial cells and gall bladder epithelium. These observations raise the possibility that a patient's own cells may be used as a source of insulinproducing cells for cell replacement in diabetes.

Journal of Endocrinology (2009) 202, 13-16
\end{abstract}

\section{Introduction}

Cell-replacement therapy involves treating diseases with functional cells derived from sources including the body's own cells. Successful cell replacement therapy in diabetes requires sufficient numbers of insulin-producing cells to be transplanted into diabetic individuals so as to achieve normal circulating glucose concentrations. However, the success of islet cell grafts is limited by two major factors. First, the immunosuppressive regimen required may have adverse effects on graft viability. Second, the number of cells as well as the number of transplants that each patient has to undergo for successful reversal of diabetes far outweighs the number of donors available. Although allogenic transplantation of cadaveric human pancreatic islets (Shapiro et al. 2000) has been till now the only successfully used cell-replacement therapy for diabetes, limited availability of cadaveric human pancreas restricts transplantation procedures to only a few diabetic individuals. The generation of insulin-producing cells has therefore become an important objective in the development of a cure for diabetes (Bonner-Weir \& Weir 2005, Miszta-Lane et al. 2006, Gangaram-Panday et al. 2007). Four possible cell sources have been considered for obtaining insulin-producing cells: existing $\beta$-cells from the other pancreatic cell types (endocrine, acinar or ductal), provoking regeneration from human embryonic stem cells, recapitulating the normal sequence of developmental events that leads to $\beta$-cell differentiation (D'Amour et al. 2006); and finally from other tissue sources, particularly those of endodermal origin (e.g. the liver), by transdifferentiation (Bonner-Weir \& Weir 2005).

\section{Pancreas, liver, and biliary system share a common developmental origin}

During development, many organs such as the liver, lung and pancreas, arise from the foregut endoderm in response to signals from adjacent germ layers (Wells \& Melton 2000). The liver (including extrahepatic biliary system) and ventral pancreas arise from the same region of the ventral foregut endoderm (Zaret \& Grompe 2008). The common ancestry of these tissues raises the intriguing possibility that it may be possible to convert one cell type to another through the process of transdifferentiation. Transdifferentiation is based on the theory that tissues derived from the same region of the developing embryo share many transcription factors but differ in the expression of only a single or a few key transcription factors known as master switch genes. Understanding the differences in the expression of these master switch genes may allow reprogramming of stem cells towards differentiated cell types or alternatively permit directed differentiation of adult cells. Based on this idea, the liver, pancreas, and gall bladder share many common features (Fig. 1) in terms of the transcription factors expressed during embryonic development and it may therefore be possible to transdifferentiate one cell type into another.

\section{Conversion of liver cells to pancreatic $\beta$-cells}

There is now a growing body of evidence to suggest that it may be possible to induce the conversion of liver cells (hepatocytes, intra-/extrahepatic biliary epithelial cells, and gall-bladder epithelium) to pancreatic lineages. Transdifferentiation has 


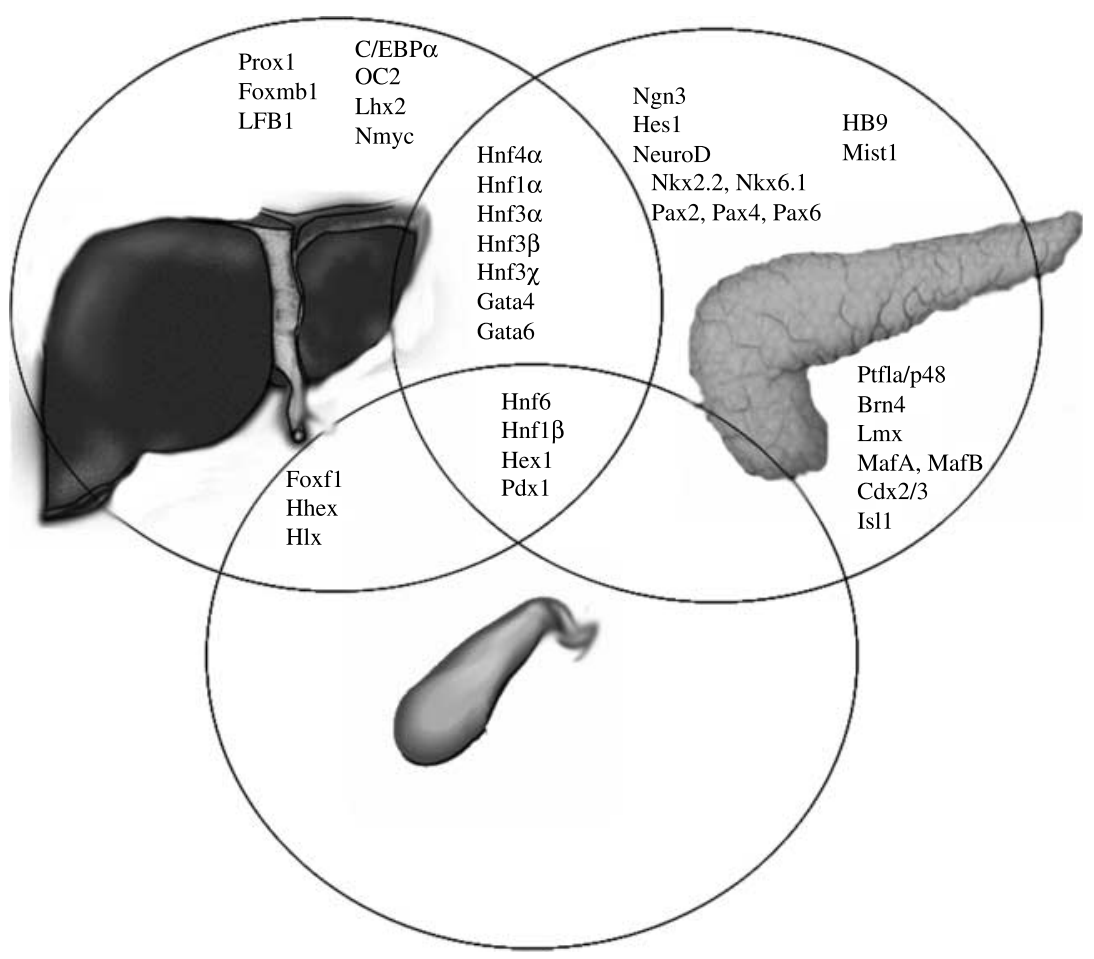

Figure 1 A schematic demonstrating the overlap of transcription factors expressed in liver, gall bladder, and pancreas during mouse embryonic development. During embryonic development, the ventral bud stems from the common biliary duct that then extends from the duodenal ampulla to the liver and gall bladder. Interestingly, one of the major developmental regulators of pancreatic development; Pdx1, is observed in gall bladder and common biliary duct (but not liver) during embryonic development. These overlapping profiles of transcription factors in liver (Costa et al. 2003, Duncan 2003, McLin \& Zorn 2006), gall bladder (Clotman et al. 2002, Coffinier et al. 2002, Kalinichenko et al. 2002, 2003, Krupczak-Hollis et al. 2004, Hunter et al. 2007, Burlison et al. 2008), and pancreas (Madsen et al. 1996, Wells \& Melton 1999, Edlund 2001a,b, Wilson et al. 2003, Habener et al. 2005) suggest the potential of resident progenitors to interconvert into specialized cell types that characterize the adult organs.

been demonstrated in a number of models including: overexpression of pancreas and duodenal homeobox gene 1 (pdx1) in liver cells (Ferber et al. 2000, Horb et al. 2003, Zalzman et al. 2005). Sumazaki et al. (2004) also demonstrated the conversion of the developing biliary system to pancreatic tissue in Hes1 null mice. These mice display gallbladder and cystic duct agenesis and conversion of the common bile duct to pancreatic tissue. The ectopic tissue possesses the full complement of pancreatic cell types: endocrine cells expressing glucagon ( $\alpha$-cells), insulin ( $\beta$-cells), somatostatin $(\delta$-cells), and pancreatic polypeptide (PP cells) in addition to exocrine cells expressing amylase and carboxypeptidase A. These results indicate a previously unknown role for Hes1 in the maintenance of the biliary phenotype and the inhibition of the pancreatic differentiation pathway. Unfortunately, use of the common bile duct as a source of tissue for the generation of $\beta$-cells is precluded, as it is essential for normal liver function. While the common bile duct may not be useful as a source of pancreatic $\beta$-cells, the gall bladder may offer an alternative starting material. Recent studies have demonstrated that gall bladder (Sahu et al. 2008) as well as human biliary duct epithelial cells contain endocrine pancreatic hormoneproducing cells. Insulin, glucagon, PP, and somatostatin proteins were observed by immunocytochemistry (Sahu et al. 2008). However, the level of insulin gene transcripts by quantitative TaqMan-based real-time PCR was at least 3000fold lower than that observed in adult human islets. These observations support the idea that population of human gall bladder or biliary epithelial cells have the potential to transcribe and produce insulin. Altogether, these findings suggest that other endoderm-derived tissues may express or retain the potential to produce endocrine pancreatic hormones, thereby providing newer sources of pancreatic progenitor cells. There is now a new addition to the list of cell types for use in $\beta$-cell therapy. Recent data suggest that the intrahepatic biliary cells may be used as a source of $\beta$-cells.

\section{Intrahepatic biliary epithelial cells can be expanded and converted to $\beta$-like cells}

In a recent issue of the Journal of Endocrinology, Gordon Weir et al. demonstrate for the first time that a sub-population of intrahepatic biliary epithelial cells (IHBECs) can be induced to a $\beta$-like phenotype (Nagaya et al. 2009). The IHBECs were initially expanded using a novel collagen matrix protocol. 
The cells maintained their biliary phenotype in culture. Following ectopic expression of Pdx1, NeuroD or Pdx1VP16 (a modified form of Pdx1 containing the VP16 transactivation domain from Herpes simplex), $\beta$-cell genes (ins 1 and 2, PC1 and 2) were expressed as well as other islet hormones including glucagon and somatostatin (albeit at lower levels than in the control islets and MIN6 cells). The presence of $\beta$-like cells in these cultures was also confirmed by the expression of $\mathrm{C}$-peptide, demonstrating the correct processing of the insulin protein. The $\beta$-cells also appeared to be functional: as they secreted insulin in response to glucose. This study raises some interesting questions regarding the use of liver-derived cells for diabetes therapy:

1. The $\beta$-cell phenotype was only present in a sub-population of IHBECs. This observation suggests that not all IHBECs are able to transdifferentiate towards a $\beta$-cell phenotype. It is important to determine the cellular origin of the 'transdifferentiated' cells and whether the cells with the highest transdifferentiation potential could be separated from the other biliary cells as endocrine progenitors.

2. The levels of insulin gene transcripts appear to be similar to islets, especially considering a subpopulation that express the relevant proteins. This may mean that either all cells express low levels of transcripts or that the subpopulation expresses a very high level of insulin gene transcripts. To distinguish these possibilities, single cell PCR could be performed on control and transdifferentiated cells.

3. While the data from animal experiments are encouraging, the question arises as to whether the same protocol can also be applied to human liver material.

\section{Summary}

Several studies discussed herein illustrate the potential of biliary duct and gall bladder epithelial cells to differentiate into islet hormone-producing cells. The possibility of obtaining biliary epithelial cells via endoscopy or gall bladder epithelia after cholecystectomy may indeed provide a source of pancreatic progenitor cells for treating diabetes. However, all these studies would be more meaningful, if protocols to expand and differentiate these cells into therapeutically significant numbers is achieved. Further studies need to be carried out to understand the potential of such progenitors for cell replacement therapy in diabetes.

\section{Declaration of interest}

None to declare.

\section{Funding}

S S is supported by research fellowship from the Council of Scientific and Industrial Research (CSIR), India. The work discussed here was funded by the UK-India Educational Research Initiative (UKIERI) research grant (DST/INT/UKIERI/SA/P-4/2008) to A A H and D T.

\section{References}

Bonner-Weir S \& Weir GC 2005 New sources of pancreatic beta-cells. Nature Biotechnology 23 857-861.

Burlison JS, Long Q, Fujitani Y, Wright CV \& Magnuson MA 2008 Pdx-1 and Ptf1a concurrently determine fate specification of pancreatic multipotent progenitor cells. Developmental Biology 316 74-86.

Clotman F, Lannoy VJ, Reber M, Cereghini S, Cassiman D, Jacquemin P, Roskams T, Rousseau GG \& Lemaigre FP 2002 The onecut transcription factor HNF6 is required for normal development of the biliary tract. Development 129 1819-1828.

Coffinier C, Gresh L, Fiette L, Tronche F, Schutz G, Babinet C, Pontoglio M, Yaniv M \& Barra J 2002 Bile system morphogenesis defects and liver dysfunction upon targeted deletion of HNF1beta. Development 129 1829-1838.

Costa RH, Kalinichenko VV, Holterman AX \& Wang X 2003 Transcription factors in liver development, differentiation, and regeneration. Hepatology 38 1331-1347.

D'Amour KA, Bang AG, Eliazer S, Kelly OG, Agulnick AD, Smart NG, Moorman MA, Kroon E, Carpenter MK \& Baetge EE 2006 Production of pancreatic hormone-expressing endocrine cells from human embryonic stem cells. Nature Biotechnology 24 1392-1401.

Duncan SA 2003 Mechanisms controlling early development of the liver. Mechanisms of Development 120 19-33.

Edlund H 2001a Developmental biology of the pancreas. Diabetes 50 S5-S9.

Edlund H $2001 b$ Factors controlling pancreatic cell differentiation and function. Diabetologia 44 1071-1079.

Ferber S, Halkin A, Cohen H, Ber I, Einav Y, Goldberg I, Barshack I, Seijffers R, Kopolovic J, Kaiser N et al. 2000 Pancreatic and duodenal homeobox gene 1 induces expression of insulin genes in liver and ameliorates streptozotocin-induced hyperglycemia. Nature Medicine 6 568-572.

Gangaram-Panday ST, Faas MM \& de Vos P 2007 Towards stem-cell therapy in the endocrine pancreas. Trends in Molecular Medicine 13 164-173.

Habener JF, Kemp DM \& Thomas MK 2005 Minireview: transcriptional regulation in pancreatic development. Endocrinology 146 1025-1034.

Horb ME, Shen CN, Tosh D \& Slack JM 2003 Experimental conversion of liver to pancreas. Current Biology 13 105-115.

Hunter MP, Wilson CM, Jiang X, Cong R, Vasavada H, Kaestner KH \& Bogue CW 2007 The homeobox gene Hhex is essential for proper hepatoblast differentiation and bile duct morphogenesis. Developmental Biology 308 355-367.

Kalinichenko VV, Zhou Y, Bhattacharyya D, Kim W, Shin B, Bambal K \& Costa RH 2002 Haploinsufficiency of the mouse Forkhead Box f1 gene causes defects in gall bladder development. Journal of Biological Chemistry 277 12369-12374.

Kalinichenko VV, Gusarova GA, Shin B \& Costa RH 2003 The forkhead box F1 transcription factor is expressed in brain and head mesenchyme during mouse embryonic development. Gene Expression Patterns 3 153-158.

Krupczak-Hollis K, Wang X, Kalinichenko VV, Gusarova GA, Wang IC, Dennewitz MB, Yoder HM, Kiyokawa H, Kaestner KH \& Costa RH 2004 The mouse Forkhead Box $\mathrm{m} 1$ transcription factor is essential for hepatoblast mitosis and development of intrahepatic bile ducts and vessels during liver morphogenesis. Developmental Biology 276 74-88.

Madsen OD, Jensen J, Blume N, Petersen HV, Lund K, Karlsen C, Andersen FG, Jensen PB, Larsson LI \& Serup P 1996 Pancreatic development and maturation of the islet B cell, Studies of pluripotent islet cultures. European Journal of Biochemistry 242 435-445.

McLin VA \& Zorn AM 2006 Molecular control of liver development. Clinics in Liver Disease 10 1-25, v.

Miszta-Lane H, Mirbolooki M, James Shapiro AM \& Lakey JR 2006 Stem cell sources for clinical islet transplantation in type 1 diabetes: embryonic and adult stem cells. Medical Hypotheses 67 909-913.

Nagaya M, Katsuta H, Kaneto H, Bonner-Weir S \& Weir GC 2009 Adult mouse intrahepatic biliary epithelial cells induced in vitro to become insulinproducing cells. Journal of Endocrinology 201 37-47. 
Sahu S, Joglekar MV, Dumbre R, Phadnis SM, Tosh D \& Hardikar AA 2008 Islet-like cell clusters occur naturally in human gall bladder and are retained in diabetic conditions. Journal of Cellular and Molecular Medicine (in press: DOI 10.1111/j.1582-4934.2008.00572.x).

Shapiro AM, Lakey JR, Ryan EA, Korbutt GS, Toth E, Warnock GL, Kneteman NM \& Rajotte RV 2000 Islet transplantation in seven patients with type 1 diabetes mellitus using a glucocorticoid-free immunosuppressive regimen. New England Journal of Medicine 343 230-238.

Sumazaki R, Shiojiri N, Isoyama S, Masu M, Keino-Masu K, Osawa M, Nakauchi H, Kageyama R \& Matsui A 2004 Conversion of biliary system to pancreatic tissue in Hes1-deficient mice. Nature Genetics 36 83-87.

Wells JM \& Melton DA 1999 Vertebrate endoderm development. Annual Review of Cell and Developmental Biology 15 393-410.

Wells JM \& Melton DA 2000 Early mouse endoderm is patterned by soluble factors from adjacent germ layers. Development 127 1563-1572.
Wilson ME, Scheel D \& German MS 2003 Gene expression cascades in pancreatic development. Mechanisms of Development 120 65-80.

Zalzman M, Anker-Kitai L \& Efrat S 2005 Differentiation of human liverderived, insulin-producing cells toward the beta-cell phenotype. Diabetes 54 2568-2575.

Zaret KS \& Grompe M 2008 Generation and regeneration of cells of the liver and pancreas. Science 322 1490-1494.

Received in final form 21 April 2009

Accepted 5 May 2009

Made available online as an Accepted Preprint

5 May 2009 